\title{
Gambaran Tingkat Kesejahteraan Psikologis Penyandang Tunanetra Dewasa Muda
}

\author{
Alabanyo Brebahama, Ratih Arruum Listyandini \\ alabanyo.brebahama@yarsi.ac.id
}

Fakultas Psikologi Universitas YARSI Jakarta, Indonesia

\begin{abstract}
Penelitian ini bertujuan untuk melihat gambaran tingkat kesejahteraan psikologis pada tunanetra yang berada pada usia dewasa muda, dengan melibatkan 36 orang tunanetra yang berusia antara 20-40 tahun serta berdomisili di DKI Jakarta. Pengukuran dilakukan dengan menggunakan alat ukur hasil adaptasi dari Psychological Well-being Scale yang dikembangkan oleh Ryff. Setelah dilakukan uji validitas konstruk dan reliabilitas melalui konsistensi internal diperoleh 31 item dengan $\alpha=0,93$. Hasil penelitian memperlihatkan bahwa $69 \%$ responden memiliki skor kesejahteraan psikologis yang tergolong tinggi, sedangkan $31 \%$ lainnya memiliki skor kesejahteraan psikologis yang tergolong rendah. Dimensi kesejahteraan psikologis yang paling tinggi adalah pada aspek personal growth, sedangkan yang paling rendah adalah pada aspek autonomy.
\end{abstract}

Kata kunci: kesejahteraan psikologis, tunanetra, dewasa muda

Dalam periode perkembangan manusia, masa dewasa merupakan saat di mana seorang individu sudah dianggap mampu untuk memikul tanggung jawab sepenuhnya sebagai orang dewasa. Pada tatanan kehidupan sosial kemasyarakatan pun, individu yang sudah memasuki usia dewasa tidak dapat lagi diperlakukan sebagai anak-anak dan diharuskan untuk berperilaku sebagai orang dewasa pada umunya. Menurut Mappiare (1983), ketika seseorang sudah memasuki usia dewasa, ia diharuskan untuk mengikuti tatanan sosial yang berlaku di lingkungan masyarakatnya. Sebagai contoh, ia dituntut untuk bekerja demi memenuhi kebutuhan hidup dan mengurus dirinya secara mandiri, serta mulai membentuk sebuah keluarga (berumah tangga). Hal ini cukup sejalan dengan penjelasan Jahja (2011) yang menyebutkan bahwa masa dewasa adalah masa awal individu dalam menyesuaikan diri terhadap pola-pola kehidupan baru dan harapan-harapan sosial baru. Pada periode tersebut, individu dituntut untuk memulai kehidupannya dan memainkan peran gender (peran sebagai suami/istri) dan peran dalam dunia kerja (karir).

Sehubungan dengan masa dewasa tersebut, Papalia, dkk. (2008) mengelompokkan periode perkembangan dewasa menjadi tiga tahapan, yakni masa dewasa muda (usia 20 hingga 40 tahun), masa dewasa madya (usia 40 hingga 60 tahun), dan masa dewasa lanjut (usia 60 tahun hingga akhir hayat). Dari ketiga tahapan tersebut, masa dewasa muda merupakan periode perkembangan yang dianggap kritis karena dalam waktu tersebutlah individu mengalami transisi dari masa remaja menuju kehidupan 
dewasa yang sesungguhnya. King (2007) memberikan istilah sebagai fase tumbuh dewasa (emerging adulthood). Pada titik perkembangan tersebut, banyak individu yang mencari jalur karir yang mereka inginkan, identitas seperti apa yang mereka ingin miliki, dan gaya hidup seperti apa yang akan mereka anut. Mereka juga dihadapkan dengan serangkaian tugas perkembangan masa dewasa awal yang harus dipenuhi seperti: memiliki teman bergaul (sebagai calon suami atau istri), belajar hidup bersama dengan suami atau istri, mulai berkeluarga dan mengelola rumah tangga, mulai bekerja dalam suatu jabatan, mulai bertanggung jawab sebagai warga negara secara layak, dan memperoleh kelompok sosial yang seirama dengan nilai-nilai yang dianutnya (Havinghaust dalam Mappiare, 1983).

Agar dapat tumbuh dan berkembang sepenuhnya sebagai orang dewasa, individu harus memenuhi berbagai tugas perkembangan. Apabila seorang dewasa tidak mampu melaksanakan harapanharapan sosial, perilakunya dianggap kurang dari standar lingkungan sekitarnya, maka dirinya dianggap sebagai orang dewasa yang jauh dari sukses (Mappiare, 1983). Sementara itu, agar seseorang mampu memenuhi tugas perkembangannya secara optimal, tentunya ia membutuhkan dukungan berbagai aspek, mulai dari kondisi fisik yang prima, kesehatan mental, maupun dukungan dari lingkungan sosial di sekitarnya.

Sehubungan dengan kondisi fisik dewasa muda, King (2007) menyebutkan bahwa individu yang berada pada usia dewasa muda mempunyai kondisi fisik dan kesehatan yang prima, bahkan sedang berada pada puncaknya. Papalia, dkk. (2008) juga menyebutkan bahwa kondisi tubuh individu pada periode dewasa muda sedang berada pada kondisi terbaik, sehingga mendukung mereka dalam memenuhi berbagai tuntutan peran sebagai orang dewasa. Sayangnya, tidak semua individu yang berada pada usia dewasa muda dikaruniai oleh kesehatan dan kesempurnaan fisik. Sebagian di antara mereka justru memiliki keterbatasan fisik, yang sering dikenal dengan penyandang disabilitas. Irwanto, dkk. (2010) menyebutkan bahwa masih banyak individu yang terhambat untuk melakukan aktivitas sosial, melaksanakan pekerjaan rumah tangga, melakukan aktivitas pekerjaan, maupun menekuni kegiatan sehari-hari akibat disabilitas yang mereka miliki. Jenis disabilitas tersebut meliputi gangguan penglihatan (tunanetra), gangguan pendengaran (tunarungu), keterbelakangan mental (retardasi mental), keterbatasan fisik (tunadaksa), dan penyakit kronis. Irwanto, dkk. (2010) juga menyebutkan bahwa penyandang disabilitas yang dalam kesehariannya disebut sebagai "orang cacat" sering dianggap sebagai warga masyarakat yang tidak produktif serta tidak mampu melaksanakan tugas dan tanggung jawabnya sehingga cenderung diabaikan.

Salah satu jenis dari disabilitas yang banyak ditemui di Indonesia adalah tunanetra. Menurut Hallahan, dkk. (2006), seseorang dinyatakan tunanetra jika setelah dilakukan berbagai upaya perbaikan terhadap kemampuan visualnya, ternyata ketajaman visualnya tidak melebihi 20/200 atau setelah dilakukan segala upaya perbaikan terhadap kemampuan visualnya, ternyata luas pandangannya tidak melebihi 20 derajat. Berdasarkan definisi di atas, keterbatasan penglihatan dapat dilihat dalam dua hal, yakni ketajaman 
penglihatan (visual acuity) dan medan penglihatan (field of vision). Ketajaman penglihatan (visual acuity) dapat diukur dengan Snellen Chart yang terdiri dari berbagai ukuran huruf dengan indeks penglihatan (Hallahan, dkk., 2006). Jika indeks angka pada Snellen Chart menunjukkan angka 20/200, maka dapat dikatakan bahwa individu tersebut mampu melihat huruf dari jarak 20 kaki, sementara orang dengan penglihatan normal mampu membaca huruf tersebut dari jarak 200 kaki. Medan penglihatan merujuk pada luasnya daerah yang dapat kita lihat pada suatu saat tertentu yang umumnya dinyatakan dalam derajat. Individu dapat dinyatakan buta secara legal jika ketajaman penglihatannya kurang dari jarak 20 kaki, ataupun luas area penglihatannya kurang dari 20 derajat (Hallahan, dkk., 2006; Mangunsong, 2009).

Imbas dari keterbatasan penglihatan tersebut tentunya sangat besar karena banyak sekali informasi yang diperoleh manusia bersumber dari stimulus visual. Berbagai hambatan yang timbul akibat gangguan pada penglihatan meliputi kesulitan orientasi dan mobilitas, sukar melihat objek yang ada di hadapan individu hingga ketidakmampuan membaca dan menulis, hambatan dalam melakukan interaksi sosial, hingga melaksanakan kegiatan sehari-hari. Mangunsong (2009) menyebutkan bahwa banyak di antara penyandang tunanetra yang sulit untuk menemukan pekerjaan akibat keterbatasan yang dimilikinya, serta pandangan negatif dari lingkungan masyarakat. Selain itu, kondisi sarana dan prasarana yang terbatas sering kali menyulitkan penyandang tunanetra untuk bepergian secara mandiri ke berbagai tempat, seperti banyaknya gorong-gorong yang terbuka di pinggir trotoar, pedagang kaki lima yang sering menggunakan bahu jalan sebagai tempat berjualan, dan sebagainya. Dalam interaksi sosial pun, penyandang tunanetra sering kali mengalami kesulitan untuk memahami dan menyesuaikan diri dengan ekspresi non verbal (Mangunsong, 2009). Ditambah pula oleh perasaan rendah diri karena keterbatasan fisik, serta stigma negatif yang melekat pada dirinya, penyandang tunanetra berpotensi mempunyai masalah dalam membina hubungan sosial dengan masyarakat di sekitarnya.

Sementara itu, penyandang tunanetra yang berada pada tahapan perkembangan dewasa muda dituntut untuk memenuhi tugas perkembangan yang ada. Di sisi lain, mereka menghadapi tantangan yang besar dalam melaksanakan tugas perkembangannya tersebut. Kondisi demikian tentunya dapat memberikan pengaruh terhadap kondisi mental penyandang tunanetra seperti yang disebutkan oleh Mappiare (1983) bahwa orang dewasa yang penyesuaian dirinya terhadap lingkungan sosial sekitarnya kurang sempurna akan merasa janggal dan tidak seimbang yang pada akhirnya membawanya pada perasaan tidak bahagia. Hal ini juga sejalan dengan penelitian Djikers (dalam Guerette dan Smedema, 2011) yang menyebutkan bahwa individu dengan disabilitas cenderung mempunyai kualitas hidup (quality of life) yang lebih rendah dibandingkan dengan individu non disabilitas akibat lebih rendahnya tingkat pendidikan, partisipasi kerja, dan penghasilan yang diperoleh individu penyandang disabilitas.

Sebagai langkah awal untuk memperoleh gambaran awal mengenai kehidupan tunanetra beserta kondisi psikologis yang mereka alami akibat 
ketunanetraan yang dialaminya, peneliti mewawancarai lima orang tunanetra di Yayasan Mitra Netra yang berlokasi di Lebak Bulus, DKI Jakarta. Yayasan tersebut merupakan sebuah lembaga swadaya masyarakat yang bergerak dalam bidang pelayanan tunanetra, mulai dari tunanetra berusia kanak-kanak awal (early childhood) hingga tunanetra lanjut usia (late adulthood). Semenjak berdiri pada tahun 1991, yayasan tersebut sudah memberikan layanan kepada kurang lebih tiga ribu orang tunanetra dengan beragam usia dan latar belakang budaya.

Berdasarkan wawancara awal dengan lima orang penyandang tunanetra yang berada pada kisaran usia 20 hingga 40 tahun di Yayasan Mitra Netra, banyak di antara mereka yang mengalami kecemasan mengenai kesulitan untuk menemukan lapangan kerja yang sesuai dan dapat memenuhi kebutuhan mereka, sukarnya untuk menemukan pasangan hidup, atau perlakuan diskriminatif dari orang "normal" yang ada di sekitarnya. Akibat hal tersebut, tidak jarang di antara mereka yang sulit menerima keadaan dirinya saat ini, dan cenderung berpandangan pesimis terhadap masa depannya nanti.

Berdasarkan gambaran tersebut, peneliti tertarik untuk melihat gambaran umum mengenai tingkat kesejahteraan psikologis tunanetra dewasa muda. Kesejahteraan psikologis (psychological well-being) sendiri dapat didefinisikan sebagai realisasi dan pencapaian optimal dari potensi seseorang. Menurut Ryff (1995), kesejahteraan psikologis (psychological well-being) merupakan sesuatu yang multidimensional. Terdapat beberapa dimensi dari kesejahteraan psikologis, yaitu: 1) individu dapat menerima segala kekurangan dan kelebihan dirinya (selfacceptance), 2) mandiri (autonomy), 3) mampu membina hubungan yang positif dengan orang lain (positive relation with others), 4) dapat menguasai lingkungannya dalam arti dapat memodifikasi lingkungan agar sesuai dengan keinginannya (environmental mastery), 5) memiliki tujuan dalam hidup (purpose in life), serta 6) terus mengembangkan pribadinya (personal growth) (Ryff, 1995). Lebih lanjut, psychological well-being bukan hanya terkait kepuasan hidup dan keseimbangan antara afek positif dan afek negatif, namun juga melibatkan persepsi dari keterlibatan dengan tantangantantangan selama hidup (Keyes, dkk., 2002).

Sebagai tokoh yang mengembangkan teori kesejahteraan psikologis (psychological well-being), Ryff (1995) sudah melakukan berbagai penelitian mengenai kesejahteraan psikologis dan mengatakan bahwa terdapat beragam faktor yang membedakan tingkat kesejahteraan psikologis, mulai dari jenis kelamin, usia, latar belakang budaya, dan sebagainya. Ryff dan Keyes (1995) juga menyebutkan bahwa kesejahteraan psikologis dapat bervariasi pada setiap golongan individu akibat dari pengalaman unik yang dimilikinya, sehingga perlu dilakukan penelitian lebih lanjut dengan melibatkan berbagai karakteristik individu.

Hingga saat ini, memang sudah banyak dilakukan penelitian dengan tema psychological well-being. Sebagai contoh misalnya, penelitian Amawidyati dan Utami (2007) yang berusaha melihat hubungan antara religiusitas dan psychological well-being pada korban gempa di Yogyakarta dan penelitian Ulimuha (2015) yang berusaha memperoleh gambaran psychological wellbeing pada pasien gagal ginjal di Rumah Sakit Muhammadiyah, Bandung. Dari 
berbagai penelitian yang sudah peneliti telusuri, kebanyakan berusaha melihat hubungan antara psychological well-being dengan variabel lain, ataupun memperoleh gambaran mengenai tingkat psychological well-being pada subjek dengan karakteristik tertentu.

Namun sayangnya, peneliti masih belum banyak menemukan penelitian tentang kesejahteraan psikologis pada penyandang disabilitas, terutama pada tunanetra. Penelitian yang dilakukan oleh Mazidah (2012) memang berusaha untuk menggali gambaran kesejahteraan psikologis tunanetra dewasa muda. Akan tetapi, penelitian ini lebih bersifat kualitatif karena menggali informasi yang berupa pengalaman fenomenologis.

Oleh karena itu, penelitian ini diharapkan mampu memperoleh data yang lebih objektif mengenai tingkat kesejahteraan psikologis tunanetra dewasa muda sebagai tindak lanjut dari penelitian kualitatif tersebut. Selain itu, hasil penelitian ini diharapkan mampu menjadi data pelengkap data kualitatif yang banyak ditemui dalam pemeriksaan psikologis secara individual. Penelitian ini juga diharapkan mampu memberikan gambaran dari setiap aspek kesejahteraan psikologis tunanetra. Dengan demikian, hal tersebut dapat menjadi dasar untuk melakukan suatu program peningkatan kesejahteraan psikologis, dimulai dari aspek yang paling buruk hingga aspek yang dinilai paling baik kondisinya.

\section{Metode \\ Desain Penelitian \\ Penelitian ini menggunakan desain non eksperimental, yaitu penelitian deskriptif kuantitatif. Pada desain ini, peneliti ingin mengukur kesejahteraan psikologis yang ada dalam diri setiap subjek penelitian,}

baik secara keseluruhan maupun tinjauan pada dimensi-dimensinya.

\section{Partisipan}

Dengan

mempertimbangkan

keterbatasan data pemerintah mengenai identitas dan alamat penduduk yang menyandang tunanetra, maka peneliti bekerja sama dengan lembaga swadaya masyarakat Yayasan Mitra Netra. Penetapan sampel dilakukan dengan metode non probability sampling, yaitu purposive sampling. Individu yang diikutsertakan dalam penelitian dipilih karena memiliki kriteria yang sudah ditetapkan oleh peneliti. Kriteria subjek penelitian adalah:

1. Berada pada tahapan perkembangan dewasa muda (usia 20 hingga 40 tahun);

2. Penyandang tuna netra. Penggolongan partisipan penelitian sebagai penyandang tunanetra didasarkan pada surat keterangan dokter mata yang pernah diperoleh subjek penelitian ketika memeriksakan kondisi penglihatannya. Keterangan tersebut juga dapat diberikan oleh instansi terkait (seperti Yayasan Mitra Netra) yang memberikan penanganan untuk penyandang tunanetra;

3. Bertempat tinggal di DKI Jakarta; dan

4. Berjenis kelamin baik laki-laki maupun perempuan.

\section{Alat Ukur Penelitian}

Instrumen yang digunakan dalam penelitian ini adalah kuesioner untuk mengukur tingkat kesejahteraan psikologis tunanetra dewasa muda. Kuesioner merupakan adaptasi dari kuesioner psychological well-being dari Ryff (1995), yang terdiri dari 42 item yang mengukur keenam dimensi kesejahteraan psikologis. 
Sebelum digunakan, kuesioner dinilai oleh expert (expert judgement), yaitu sebanyak empat orang yang terdiri dari dua orang dosen Fakultas Psikologi Universitas YARSI dan dua orang praktisi di bidang pelayanan dan pengembangan tunanetra di Yayasan Mitra Netra.

Pengisian kuesioner dilakukan secara individual melalui wawancara oleh tim peneliti. Adapun untuk menjawab kuesioner PWB, subjek hanya perlu menyebutkan pilihan skala Likert dari angka 1 hingga angka 6 . Angka 1 mengartikan bahwa subjek sangat tidak setuju dengan pernyataan yang dibacakan. Sementara itu, angka 6 mengartikan bahwa subjek sangat setuju dengan pernyataan yang dibacakan.

Uji validitas menggunakan validitas konstruk dan reliabilitas menggunakan konsitensi internal. Hasil analisis menunjukkan bahwa kuesioner PWB yang digunakan valid dan reliabel dengan total 31 butir yang dapat dipakai. Koefisien reliabilitas adalah $\alpha=0,93$ dengan nilai corrected item total correlation ( $\mathrm{r}$ ) berkisar antara 0,2-0,6.

\section{Teknik Analisis Data}

Dengan jenis data yang bersifat kuantitatif dan tujuan penelitian yang bersifat deskriptif, maka analisis data menggunakan statistik deskriptif dengan bantuan SPSS.

\section{Hasil}

\section{Profil Demografis Responden}

Dalam bagian ini akan dideskripsikan data-data yang terkait dengan hasil penelitian, mulai dari data mengenai persebaran jenis kelamin subjek penelitian, lokasi tempat tinggal subjek penelitian, persebaran usia, serta golongan tunanetra.
Tabel 1.

Persebaran Data Demografis Responden.

\begin{tabular}{cccc}
\hline $\begin{array}{c}\text { Variabel } \\
\text { Demografis }\end{array}$ & Kategori & $\begin{array}{c}\text { Jumlah } \\
\text { (Orang) }\end{array}$ & $\mathbf{( \% )}$ \\
\hline $\begin{array}{c}\text { Jenis } \\
\text { Kelamin }\end{array}$ & Laki-laki & 18 & 50 \\
& Perempuan & 18 & 50 \\
Tempat & Jakarta Selatan & 26 & 72,2 \\
Tinggal & Jakarta Timur & 9 & 25 \\
& Jakarta Barat & 1 & 2,8 \\
\hline Usia & 20-24 tahun & 7 & 19,4 \\
& 25-30 tahun & 19 & 52,8 \\
& $31-35$ tahun & 3 & 8,4 \\
& $36-40$ tahun & 7 & 19,4 \\
\hline Pendidikan & S1 & 19 & 52,4 \\
& D3 & 2 & 5,5 \\
& SMA & 12 & 33,4 \\
& SMP & 1 & 2,8 \\
& SD & 2 & 5,5 \\
\hline Penghasilan & $<1.500 .000$ & 18 & 50 \\
& $1.600 .000-$ & 12 & 33,4 \\
& 3.000 .00 & & \\
& $3.100 .000-$ & 5 & 13,8 \\
& 4.500 .000 & & \\
& 4.600.000 & 1 & 2,8 \\
\hline Totally blind & 17 & 47,6 \\
& Low vision & 19 & 52 \\
\hline & & &
\end{tabular}

Berdasarkan persebaran data yang ditampilkan pada Tabel 1, tampak bahwa sebagian besar responden tinggal di Jakarta Selatan (72,2\%) dan berusia 25-30 tahun $(52,8 \%)$. Sementara itu, jumlah responden pria dan wanita tampak berimbang. Selanjutnya, jika ditinjau dari tingkat pendidikan, sebagian besar responden memiliki latar belakang pendidikan sarjana $(52,4 \%)$. Kemudian, dari segi penghasilan, sebagian besar mempunyai penghasilan di bawah upah minimum regional (saat penelitian ini dilakukan UMR ditetapkan sebesar Rp 2.700.000). Selanjutnya, berdasarkan penggolngan tunanetra, jumlah responden yang totally blind dengan low vision hampir setara. Tampak bahwa jumlah responden yang totally blind adalah sebesar $47,6 \%$ dan responden yang low vision adalah sebanyak 52,4\%. 
Gambaran Psychological Well-being pada Penyandang Tunanetra

Tabel 2 menunjukkan hasil data deskriptif yang didapatkan dari analisis statistik, di mana jumlah partisipan $(\mathrm{N})$ adalah 36 orang. Sementara itu, nilai minimum sebesar 67 adalah skor terkecil yang diperoleh subjek penelitian dalam pengisian kuesioner PWB. Kemudian, nilai maksimum sebesar 165 merupakan skor tertinggi yang diperoleh subjek penelitian dalam pengisian kuesioner PWB. Adapun nilai rata-rata yang diperoleh dari seluruh subjek adalah 140,4 dengan standar deviasi 21,3.

Tabel 2.

Gambaran PWB Responden.

\begin{tabular}{cc}
\hline Data Deskriptif & Nilai \\
\hline N (Jumlah) & 36 \\
Nilai Minimum & $67(2,23)$ \\
Nilai Maksimum & $165(5,5)$ \\
Mean & $140,4(4,68)$ \\
Standar Deviasi & 21,3 \\
\hline
\end{tabular}

Selanjutnya, pada tabel 3 terdapat kategorisasi psychological well-being berdasarkan nilai rata-rata (mean) yang terdapat di Tabel 2.

Tabel 3.

Pengelompokan Kategori Tingkat Kesejahteraan Psikologis.

\begin{tabular}{ccc}
\hline $\begin{array}{c}\text { Kategori Psychological } \\
\text { Well-being }\end{array}$ & Jumlah & Persentase \\
\hline Rendah (<Mean) & 11 & $31 \%$ \\
Tinggi (>Mean) & 25 & $69 \%$ \\
\hline
\end{tabular}

Berdasarkan kategorisasi pada Tabel 3, tampak bahwa sebagian besar responden memiliki kesejahteraan psikologis yang tergolong tinggi, yaitu sebanyak 25 orang atau sebesar 69\%. Responden yang tergolong memiliki kesejahteraan psikologis rendah adalah sebanyak 11 orang atau sebesar $31 \%$. Bila ditinjau berdasarkan dimensinya, berikut adalah profil gambaran kesejahteraan psikologis responden.

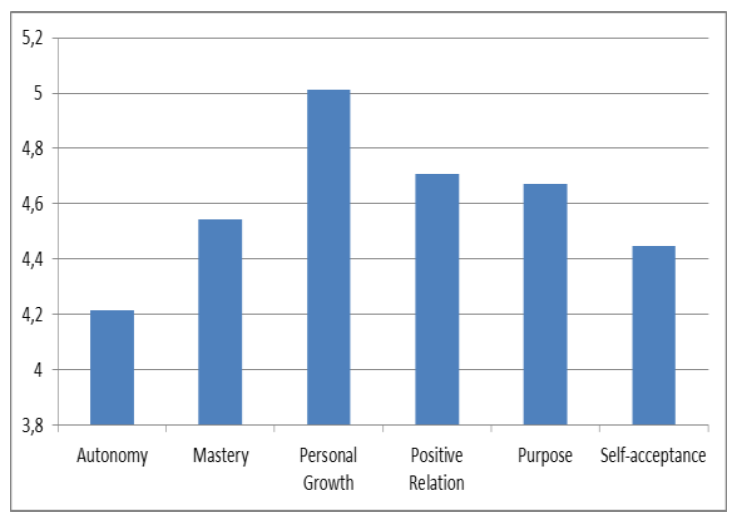

Gambar 1. Ilustrasi Tingkat Kesejahteraan Psikologis Setiap Dimensi.

Berdasarkan data, tampak bahwa dimensi kesejahteraan psikologis yang paling baik adalah pada dimensi personal growth, sedangkan dimensi kesejahteraan psikologis yang paling rendah adalah pada dimensi autonomy.

\section{Diskusi}

Hasil penelitian menunjukkan bahwa 69\% tunanetra memiliki skor kesejahteraan psikologis yang tergolong tinggi, sedangkan sisanya memiliki skor kesejahteraan psikologis yang tergolong rendah. Hal ini memperlihatkan bahwa tidak selamanya individu dewasa muda yang mengalami kondisi ketunanetraan memiliki kesejahteraan psikologis yang rendah. Ryff (1995) memang menyebutkan bahwa terdapat empat faktor yang mempengaruhi tingkat kesejahteraan psikologis individu, seperti usia, jenis kelamin, tingkat pendidikan, dan status sosial ekonomi. Namun, tampak bahwa tidak selamanya empat hal tersebut berpengaruh signifikan terhadap kesejahteraan psikologis tunanetra. Sebagai contoh, sebagian besar responden masih berpenghasilan di bawah upah minimum regional ( $\operatorname{Rp} 2.700 .000)$, namun 
mereka ada yang tetap mempunyai skor kesejahteraan psikologis yang tinggi. Selain itu, banyak di antara mereka yang masih berdomisili (tinggal) bersama orang tuanya (terlihat pada butir mengenai kemampuan membangun tempat tinggal dan gaya hidup yang sesuai dengan selera sendiri), namun banyak di antaranya tetap sejahtera secara psikologis.

Hal lain yang justru menjadi salah satu catatan penting adalah seluruh responden dalam penelitian ini pernah (dan masih) terlibat dalam organisasi ketunanetraan, serta terdaftar sebagai klien yang menerima layanan konseling maupun pendidikan di Yayasan Mitra Netra. Hal ini akhirnya memungkinkan mereka untuk bertemu dan berinteraksi dengan individu yang sama-sama mengalami ketunanetraan, serta saling berbagi cerita satu sama lain. Keterlibatan tersebut juga memungkinkan mereka untuk mendapatkan konseling (dari konselor yang juga penyandang tunanetra) dan berpartisipasi dalam kegiatan pengembangan keterampilan (seperti pendidikan Bahasa Inggris, program komputer untuk tunanetra, keterampilan orientasi mobilitas membaca dengan menggunakan huruf braille, memasak, dan berbagai jenis keterampilan lain).

Walaupun penelitian ini tidak bermaksud untuk melihat hubungan antar variabel, seperti dukungan sosial dan partisipasi dalam kegiatan pengembangan diri dengan kesejahteraan psikologis, namun peneliti menduga bahwa faktor dukungan sosial dan keterlibatan dalam kegiatan sangat berperan terhadap tingginya kesejahteraan psikologis para tunanetra dalam penelitian ini. Hal tersebut tampak dari tingginya rata-rata skor dimensi personal growth dan positive relation with others. Sebab, dengan adanya keterlibatan peserta dalam program pendidikan di Yayasan Mitra Netra membuat mereka merasa memiliki pertumbuhan pribadi terutama pada aspek keterampilan. Selain itu, dari wawancara singkat terhadap seluruh responden selama penelitian ini berlangsung, mereka merasakan hubungan yang positif ketika berada dalam lingkungan sesama tunanetra.

Selanjutnya, penelitian ini juga tidak bertujuan untuk melihat hubungan antara variabel dukungan sosial dan aspek kepribadian terhadap kesejahteraan psikologis. Akan tetapi, peneliti menduga adanya kontribusi kedua aspek tersebut terhadap kesejahteraan psikologis subjek penelitian ini. Sebagai gambaran, seluruh partisipan penelitian ini merupakan klien yang pernah mendapatkan penanganan di Yayasan Mitra Netra, dan sebagian besar di antaranya terlibat dalam kegiatan organisasi masyarakat yang bergerak di bidang ketunanetraan, seperti Persatuan Tunanetra Indonesia dan Ikatan Tunanetra Muslim Indonesia. Dengan keterlibatan subjek penelitian sebagai klien di Yayasan Mitra Netra maupun pengurus organisasi kemasyarakatan di atas, mereka memiliki kesempatan untuk berinteraksi dengan tunanetra lain. Fenomena tersebut sejalan dengan penelitian yang dilakukan oleh Guerette dan Smedema (2011) mengenai hubungan antara persepsi dukungan sosial terhadap kualitas hidup orang dewasa yang mengalami gangguan penglihatan. Penelitian tersebut menemukan bahwa orang yang merasa bahwa lingkungan di sekitarnya mampu memberikan dukungan positif terhadap dirinya cenderung mempunyai kualitas hidup yang lebih baik.

Sementara itu, rendahnya aspek otonomi diduga lebih disebabkan oleh banyaknya tunanetra yang masih 
bergantung kepada orang-orang di sekitarnya. Dari data, diketahui bahwa $50 \%$ tunanetra berpenghasilan lebih rendah dari Rp 1.500.000. Seluruh tunanetra yang menjadi subjek dalam penelitian ini masih tinggal bersama dengan orang tua ataupun kerabatnya dan belum memiliki tempat tinggal sendiri. Hal inilah yang diduga berdampak terhadap rendahnya aspek otonomi tunanetra dalam kehidupan sehari-hari.

Hal lain yang juga menjadi catatan penting bagi peneliti adalah keterbatasan jumlah subjek penelitian. Walaupun Yayasan Mitra Netra memberikan kontak 50 orang tunanetra dewasa muda, namun tidak semuanya mau berpartisipasi dalam penelitian ini. Hal tersebut berhubungan dengan rendahnya keterbukaan diri dari tunanetra yang masih menjalani konseling dan rehabilitasi. Selain itu, sebagian besar subjek penelitian ini berdomisili di Jakarta Selatan, Jakarta Timur, dan Jakarta Barat sehingga terlihat bahwa penelitian ini kurang mewakili tunanetra yang berdomisili di Jakarta Pusat dan Jakarta Utara. Hal inilah yang menjadi kelemahan dari penelitian ini.

Walaupun memiliki keterbatasan dalam jumlah subjek penelitian, maupun kurang proporsionalnya keterwakilan sampel di setiap kotamadya DKI Jakarta, penelitian ini diharapkan dapat menjadi dasar bagi penelitian selanjutnya. Sebab, penelitian Psikologis dalam bidang disabilitas di Indonesia masih sedikit jumlahnya jika dibandingkan dengan penelitian dalam topik serupa di negara maju. Selain itu, penelitian ini diharapkan dapat dijadikan salah satu dasar acuan lembaga penyedia layanan bagi tunanetra dalam menentukan program yang paling bermanfaat bagi tunanetra.
Sebagai pertimbangan bagi penelitian selanjutnya, penting untuk melibatkan jumlah sampel yang lebih banyak dan proporsional. Selain itu, akan lebih menarik jika penelitian serupa diarahkan untuk melihat keterkaitan berbagai variabel lainnya dengan tingkat kesejahteraan psikologis (psychological well-being), seperti persepsi dukungan sosial, resiliensi, penerimaan diri, dan sebagainya.

Kemudian, mengingat masih jarangnya penelitian dengan tema kesejahteraan psikologis pada individu penyandang disabilitas, peneliti berniat untuk menggali lebih jauh kesejahteraan psikologis (psychological well-being) pada penyandang disabilitas lain, seperti tunarungu, tunadaksa, learning disorder, maupun jenis disabilitas lain. Dengan demikian akan diperoleh sebuah penelitian komparatif yang mendeskripsikan tingkat psychological well-being pada setiap jenis ketunaan/disabilitas.

\section{Kesimpulan}

Berdasarkan hasil pengolahan data, dapat dilihat bahwa dari 36 responden yang berpartisipasi dalam penelitian ini, $69 \%$ orang memiliki tingkat kesejahteraan psikologis (psychological well-being) yang tergolong tinggi. Sementara itu, tingkat kesejahteraan psikologis $31 \%$ orang lainnya masih tergolong rendah. Bila ditinjau dari dimensinya, tampak bahwa dimensi kesejahteraan psikologis yang paling tinggi adalah pada aspek personal growth, sedangkan aspek yang paling rendah adalah pada dimensi autonomy. 


\section{Daftar Pustaka}

Amawidyati, S. A. G. \& Utami, M. S. (2007). Religiusitas dan psychological well-being pada korban gempa. Jurnal Psikologi UGM, 34(2), 164-176.

Guerette, A. R. \& Smedema, S. M. (2011). The relationship of perceived social support with well-being in adults with visual impairment. Journal of Visual Impairment and Blindness, 425-239.

Hallahan, D. P., Kauffman, J. M., \& Pullen, P. C. (2009). Exceptional Learners (1 $1^{\text {th }}$ edition). Boston: Pearson Education Inc.

Irwanto, Kasim, R. E., Fransiska, A., Lusli, M., \& Siradj, O. (2010). Analisis Situasi Penyandang Disabilitas di Indonesia. Depok: Pusat Kajian Disabilitas Fakultas Ilmu-ilmu Sosial dan Politik Universitas Indonesia.

Jahja, Y. (2011). Psikologi Perkembangan. Jakarta: Prenada Metia Group.

Keyes, C., Shmotkin, D., \& Ryff, C. D. (2002). Optimizing well-being: The empirical encounter of two tradition. Journal of Personality and Social Psychology, 82(6), 1007-1022.

King, Laura. (2007). The Science of Psychology (The Appreciative View). New York: McGraw-Hill.

Mangunsong, F. (2009). Psikologi dan Pendidikan Anak Berkebutuhan Khusus (Jilid Kesatu). Depok: Lembaga Pengembangan Sarana Pengukuran dan Pendidikan Psikologi (LPSP3) Fakultas Psikologi Universitas Indonesia.

Mappiare, A. (1983). Psikologi Orang Dewasa. Surabaya: Usaha Nasional.

Mazidah, L. (2012). Kesejahteraan Psikologis Tunanetra Dewasa Dini. Yogyakarta: Program Studi Psikologi Fakultas Ilmu Sosial dan Humaniora Universitas Islam Negeri Sunan Kalijaga.
Papalia, D. E., Olds, S. W., \& Feldman, D. (2008). Human Development $\left(10^{\text {th }}\right.$ edition). New York: McGraw-Hill.

Ryff, C. D. (1995). Psychological Wellbeing in adult life. Current Direction in Psychological Science, 4(4).

Ryff, C. D. \& Keyes, C. L. M. (1995). The structure of psychological well-being revisited. Journal of Personality and Social Psychology, 69, 719-727.

Ulimuha, L. R. (2015). Psychological Well-being Pada Pasian Gagal Ginjal Yang Menjalani Terapi Hemodialisis di Rumah Sakit Muhammadiyah Bandung. Bandung: Universitas Islam Bandung. 